\title{
Bioluminescence capability and intensity in the dinoflagellate Alexandrium species
}

\author{
Sang Ah Park ${ }^{1}$, Hae Jin Jeong ${ }^{1,2, *}$, Jin Hee Ok ${ }^{1}$, Hee Chang Kang ${ }^{1}$, Ji Hyun You ${ }^{1}$, Se Hee \\ Eom $^{1}$, Yeong Du Yoo ${ }^{3}$ and Moo Joon Lee ${ }^{4}$ \\ ${ }^{1}$ School of Earth and Environmental Sciences, College of Natural Sciences, Seoul National University, Seoul 08826, Korea \\ ${ }^{2}$ Research Institute of Oceanography, Seoul National University, Seoul 08826, Korea \\ ${ }^{3}$ Department of Marine Biotechnology, College of Ocean Sciences, Kunsan National University, Kunsan 54150, Korea \\ ${ }^{4}$ Department of Marine Biotechnology, Anyang University, Incheon 23038, Korea
}

Some species in the dinoflagellate genus Alexandrium are bioluminescent. Of the 33 formally described Alexandrium species, the bioluminescence capability of only nine species have been tested, and eight have been reported to be bioluminescent. The present study investigated the bioluminescence capability of seven Alexandrium species that had not been tested. Alexandrium mediterraneum, A. pohangense, and A. tamutum were bioluminescent, but A. andersonii, A. hiranoi, A. insuetum, and A. pseudogonyaulax were not. We also measured the bioluminescent intensity of A. affine, A. fraterculus, A. mediterraneum, A. ostenfeldii, A. pacificum, A. pohangense, A. tamarense, and A. tamutum. The mean 200-second-integrated bioluminescence intensity per cell ranged from 0.02 to $32.2 \times 10^{4}$ relative luminescence unit per cell $\left(\mathrm{RLU}\right.$ cell-1 ${ }^{-1}$ ), and the mean maximum bioluminescence intensity per cell per second ( $\left.\mathrm{BL}_{\mathrm{Max}}\right)$ ranged from 0.01 to 10.3 $\times 10^{4} \mathrm{RLU}$ cell $^{-1} \mathrm{~s}^{-1}$. BL $\mathrm{L}_{\mathrm{Max}}$ was significantly correlated with the maximum growth rates of Alexandrium species, except for A. tamarense. A phylogenetic tree based on large subunit ribosomal DNA (LSU rDNA) showed that the bioluminescent species A. affine, A. catenella, A. fraterculus, A. mediterraneum, A. pacificum, and A. tamarense formed a large clade. However, the toxicity or mixotrophic capability of these species was split. Thus, their bioluminescence capability in this clade was more consistent than their toxicity or mixotrophic capability. Phylogenetic trees based on LSU rDNA and the luciferase gene of Alexandrium were consistent except for A. pohangense. The results of the present study can provide a basis for understanding the interspecific diversity in bioluminescence of Alexandrium.

Key Words: harmful algal bloom; luciferase gene; luminescence; protist; red tide

\section{INTRODUCTION}

Bioluminescence, the production of light by living organisms, is a widespread phenomenon in nature (Haddock et al. 2010, Valiadi and Iglesias-Rodriguez 2013). Light is produced when luciferase (enzyme) binding with luciferin causes an oxidation reaction of luciferin (substrate) (McCapra 1976, Wilson and Hastings 2013). A majority of the bioluminescent organisms reside in the ocean (Shimomura 2006, Widder 2010).

Dinoflagellates are ubiquitous protists and one of the most common bioluminescent producers (Haddock et al. 2010, Le Tortorec et al. 2016, Kang et al. 2019, Cusick and Widder 2020, Jang and Jeong 2020, Lee et al. 2020).
(9) $\$$ This is an Open Access article distributed under the terms of the Creative Commons Attribution Non-Commercial License (http://creativecommons.org/licenses/by-nc/3.0/) which permits unrestricted non-commercial use, distribution, and reproduction in any medium, provided the original work is properly cited.
Received October 30, 2021, Accepted December 6, 2021

*Corresponding Author

E-mail: hjjeong@snu.ac.kr

Tel: +82-2-880-6746, Fax: +82-2-874-9695 
In dinoflagellates, bioluminescence is a defense mechanism against predation and helps attract secondary predators (a function sometimes called a burglar alarm) (Esaias and Curl 1972, Haddock et al. 2010, Valiadi and Iglesias-Rodriguez 2013, Lindström et al. 2017). Several species of bioluminescent dinoflagellates form red tides, dense algal blooms (Valiadi et al. 2012, Cusick and Widder 2014, Jeong et al. 2015); due to their brightness, fish, mammals, and ships passing red-tide patches can be detected at night (Cram and Schülein 1974, Rohr et al. 1998, Miller et al. 2005). Thus, dinoflagellate bioluminescence has been studied in terms of ecophysiology and military uses. However, the bioluminescent capability of dinoflagellates has been tested in only a small portion of 3,450 formally described dinoflagellate species (e.g., Sweeney 1963, Kelly 1968, Swift et al. 1995, Latz and Jeong 1996, Jeong et al. 2021). Among the tested dinoflagellate species, only 70 ( $<3 \%$ of 3,450 formally described dinoflagellates) have been reported to be bioluminescent (Marcinko et al. 2013, Cusick and Widder 2014, 2020). Furthermore, the bioluminescence intensity of only 14 species ( $<1 \%$ of 3,450 formally described dinoflagellates) has been reported, including that of Alexandrium tamarense, A. catenella, Ceratocorys horrida, Lingulodinium polyedra, Noctiluca scintillans, Pyrodinium bahamense, Protoperidinium spp., Pyrocystis spp., and Tripos spp. (Seliger et al. 1969, Esaias and Curl 1972, Esaias et al. 1973, Swift et al. 1973, White 1979, Widder and Case 1981, Lapota et al. 1989, Latz and Lee 1995, Sullivan and Swift 1995, Latz et al. 2004, Cussatlegras and Le Gal 2007, Eckert 2015). Thus, the bioluminescent capability and intensity of more dinoflagellate species should be explored.

The genus Alexandrium is widely distributed across coastal waters and is a major organism causing red tides or harmful algal blooms (Anderson et al. 2012, Jeong et al. 2017). However, among the 33 known Alexandrium species (Guiry and Guiry 2021), only nine species have been tested for the bioluminescence capability (Esaias and Curl 1972, Esaias et al. 1973, Liu et al. 2004, Baker et al. 2008, Latz et al. 2008, Kremp et al. 2009, Martínez et al. 2016). Furthermore, bioluminescence intensity has been reported in only three Alexandrium species (Esaias and Curl 1972, White 1979), and it widely ranged from $2 \times 10^{4}$ to $7 \times 10^{7}$ photons per cell. As the bioluminescence intensity of Alexandrium spp. may be species-dependent, it should be measured in more Alexandrium species. In addition, bioluminescence intensity should be assessed using the same technique across species, in order to reveal the potential factors that affect the bioluminescence intensity.
In the present study, the bioluminescence capability of seven Alexandrium species (A. andersonii, A. hiranoi, A. insuetum, A. mediterraneum, A. pohangense, A. pseudogonyaulax, and A. tamutum) was investigated. The bioluminescence intensity of eight Alexandrium species (A. affine, A. fraterculus, A. mediterraneum, A. ostenfeldii, A. pacificum, A. pohangense, A. tamarense, and A. tamutum) was also explored. Moreover, the effects of cell size, mixotrophic ability, toxicity, maximum swimming speed, and maximum growth rate on bioluminescence intensity were investigated in eight Alexandrium species. In addition, the sequence of the luciferase gene (lcf) was analyzed in A. fraterculus, A. mediterraneum, A. pohangense, and A.tamutum, and the phylogenetic trees based on the $l c f$ and large subunit ribosomal DNA (LSU rDNA) of Alexandrium spp. were compared. The results of the present study can provide a basis for understanding the interspecific diversity in the bioluminescence capability and intensity of Alexandrium.

\section{MATERIALS AND METHODS}

\section{Cultures of experimental organisms}

Cells of A. affine, A. fraterculus, A. mediterraneum, A. pacificum, A. pohangense, and A. tamutum were isolated from Korean coastal waters and then established using two serial single-cell isolations (Table 1). Cultures of the other six Alexandrium species (A. andersonii, A. minutum, A. insuetum, A. ostenfeldii, A. tamarense, and A. hiranoi) used in the present study were obtained from the National Center for Marine Algae and Microbiota (NCMA; USA), Roscoff Culture Collection (RCC; France), and the Microbial Culture Collection at the National Institute for Environmental Studies (NIES Collection, Japan). All experimental cultures were maintained at $20^{\circ} \mathrm{C}$ in a chamber under cool white fluorescent lights $(20 \mu \mathrm{mol}$ photons $\mathrm{m}^{-2} \mathrm{~s}^{-1}$ ) on a $14: 10 \mathrm{~h}$ light / dark cycle. The culture of $A$. pohangense was grown mixotrophically by feeding on Margalefidinium polykrikoides. Other cultures were grown autotrophically in F/2 (Guillard and Ryther 1962) or L1 (Guillard and Hargraves 1993) seawater medium without silicate (Table 1).

\section{Bioluminescence capability}

The bioluminescence capability of each Alexandrium species was tested when the cultures reached their late exponential to early stationary phases. Cultures of 
the seven Alexandrium species were mechanically and chemically stimulated (Table 1). For mechanical stimulation, dense Alexandrium cultures were placed in the dark for $3 \mathrm{~h}$ and then shaken by hand in a dark room. During mechanical stimulation, bioluminescence images were captured using a Canon EOS R with a Canon RF $50 \mathrm{~mm}$ F1.2L lens (Canon, Tokyo, Japan) at aperture F1.2, shutter speed $30 \mathrm{~s}$, ISO4000.

If mechanically stimulated bioluminescence was not visible using the digital camera, chemical stimulation was conducted. For the chemical stimulation, four 200 $\mu \mathrm{L}$ aliquots of dense cultures of each Alexandrium species were placed in four wells of Corning 96-well white plates (Corning Life Sciences, Amsterdam, Netherlands). Four culture media without Alexandrium cells were also placed in four wells as controls, and analysis of these wells confirmed no bioluminescence. The bioluminescence analysis of each Alexandrium species was performed 3 $\mathrm{h}$ after the beginning of the dark phase, when the cells are known to be fully dark-adapted and produce highly stimulated bioluminescence (Biggley et al. 1969, Krasnow et al. 1980). Chemically stimulated bioluminescence was measured after the addition of $50 \mu \mathrm{L}$ of $1 \mathrm{M}$ acetic acid to the well (Hastings and Sweeney 1957, Fogel and Hastings 1972, Sweeney 1986). Acidification by the addition of acetic acid, which reduces the intracellular $\mathrm{pH}$ to $<6-7$, is known to bind the luciferase and luciferin of bioluminescent species (Fogel and Hastings 1972, Sweeney 1986, Von Dassow and Latz 2002). The bioluminescence response was assayed for $200 \mathrm{~s}$ using a GloMax Navigator microplate luminometer (Promega, Madison, WI, USA).

\section{Measurement of bioluminescence intensity}

To measure the bioluminescence intensity of eight Alexandrium species, triplicate $1 \mathrm{~mL}$ aliquots were removed from a culture of each Alexandrium species and then fixed with 5\% acid Lugol's solution, and Alexandrium cells were enumerated under a light microscope to determine the density of each culture. Cells were added to a $50 \mathrm{~mL}$ culture flask to reach the target cell density of 1,000 cells $\mathrm{mL}^{-1}$, using media in which the cells were grown. A $200 \mu \mathrm{L}$ aliquot of diluted culture was placed in a well in a Corning 96-well white plate (Corning Life Sciences), with four replicates. The analysis of bioluminescence was conducted using the method described above.

\section{Bioluminescence data analysis}

To obtain the bioluminescence intensity per cell per second of each Alexandrium species, the mean value obtained from the four control wells (containing seawater without bioluminescent Alexandrium cells) was subtracted from the bioluminescence intensity value of the cells in one well, and then the value was divided by the total number of cells in the well. Using the data on bioluminescence intensity per cell per second of each Alexandrium species, several parameters, such as the integrated

Table 1. Information on the isolation and maintenance of the experimental organisms and also Alexandrium species in which bioluminescence capability was previously tested or newly tested

\begin{tabular}{|c|c|c|c|c|c|c|c|}
\hline Organisms & Strain name & Location & Date & $\mathrm{T}$ & $\mathrm{S}$ & Media / Prey & Biolu \\
\hline Alexandrium andersonii & CCMP2222 & Gulf of Naples, Italy & Aug 1, 1996 & - & - & $\mathrm{L} 1$ & NewBL \\
\hline A. minutum & CCMP1888 & Laguna Obidos, Portugal & - & - & - & $\mathrm{L} 1$ & PNB \\
\hline A. tamutum & ATSH1609 & Shiwha, Korea & Sep 9, 2016 & 25.9 & 32.6 & $\mathrm{~F} / 2$ & NewBL \\
\hline A. insuetum & CCMP2082 & Uchiumi Bay, Japan & Jun 6, 1985 & - & - & $\mathrm{F} / 2$ & NewBL \\
\hline A. ostenfeldii & NIES-4274 & Lake Koyama, Japan & Nov 29, 2016 & - & - & $\mathrm{F} / 2$ & $\mathrm{~PB}$ \\
\hline A. pacificum & KSUDinoE4 & Kunsan, Korea & Sep 2020 & 23.5 & 29.2 & $\mathrm{~F} / 2$ & PB \\
\hline A. affine & AATA1308 & Taean, Korea & Aug 14, 2013 & 21.5 & 32.2 & $\mathrm{~F} / 2$ & PB \\
\hline A. pohangense & APPH1409 & Pohang, Korea & Sep 2014 & 23.3 & 31.1 & $\mathrm{Mp}$ & NewBL \\
\hline A. fraterculus & AFYS1309 & Yeosu, Korea & Sep 6, 2013 & 23.4 & 32.8 & $\mathrm{~L} 1$ & PB \\
\hline A. mediterraneum & AMYS1807 & Yeosu, Korea & Jul 2018 & 24.2 & 30.0 & $\mathrm{~F} / 2$ & NewBL \\
\hline A. tamarense & CCMP115 & English Channel, UK & Jun 24, 1957 & - & - & $\mathrm{F} / 2$ & $\mathrm{~PB}$ \\
\hline A. pseudogonyaulax & KSUDinoB4 & Kunsan, Korea & Sep 2020 & 23.5 & 29.2 & $\mathrm{~F} / 2$ & NewBL \\
\hline A. hiranoi & NIES-3611 & Muroto Cape, Japan & Apr 29, 2008 & - & - & $\mathrm{F} / 2$ & NewBL \\
\hline Protoceratium reticulatum & RCC4104 & Pacific Ocean, Japan & Aug 30, 2013 & - & - & $\mathrm{L} 1$ & $\mathrm{~PB}$ \\
\hline Lingulodinium polyedra & CCMP1931 & La Jolla, California, USA & May 1998 & - & - & $\mathrm{L} 1$ & $\mathrm{~PB}$ \\
\hline
\end{tabular}

Culture information was obtained from the National Center for Marine Algae and Microbiota (NCMA; USA), Roscoff Culture Collection (RCC; France), and Microbial Culture Collection at the National Institute for Environmental Studies (NIES; Japan).

$\mathrm{T}$, temperature $\left({ }^{\circ} \mathrm{C}\right) ; \mathrm{S}$, salinity; NewBL, newly tested for bioluminescence in the present study; PNB, previously known to be not bioluminescent; $\mathrm{PB}$, previously known to be bioluminescent; Mp, Margalefidinium polykrikoides. 
bioluminescence intensity per cell for $200 \mathrm{~s}$ and the maximum bioluminescence intensity per cell per second, were calculated as described by Latz and Lee (1995). The mean 200-second-integrated bioluminescence intensity per cell $\left(\mathrm{BL}_{\text {Int20os }}\right)$ was calculated by averaging the sums of the bioluminescence intensity per cell per $200 \mathrm{~s}$ in four wells. Furthermore, the mean maximum bioluminescence intensity per cell per second $\left(\mathrm{BL}_{\mathrm{Max}}\right)$ was calculated by averaging the highest bioluminescence intensities per cell per second in the four wells. In the present study, relative luminescence unit per cell (RLU cell $\left.{ }^{-1}\right)$ and RLU per cell per second (RLU cell ${ }^{-1} \mathrm{~s}^{-1}$ ) were used as the units of $\mathrm{BL}_{\text {Int20os }}$ and $\mathrm{BL}_{\mathrm{Max}}$, respectively (Lindström et al. 2017).

\section{Sequencing large subunit ribosomal DNA and Icf}

To obtain the LSU rDNA and $l c f$ sequences, a $10 \mathrm{~mL}$ aliquot of each dense culture was harvested at 3,667 $\mathrm{g}$ $(4,000 \mathrm{rpm})$ for $10 \mathrm{~min}$ in a $15 \mathrm{~mL}$ conical tube. The gDNA was extracted from the pellet using a Wizard SV Genomic DNA Purification System (Promega).

The amplification reaction mixtures $(50 \mu \mathrm{L}$ in total volume) were as follows: $5 \mu \mathrm{L}$ of $10 \times$ F-StarTaq buffer, $1 \mu \mathrm{L}$ of

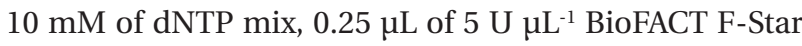
Taq DNA polymerase (BioFACT Co., Ltd., Daejeon, Korea), $2 \mu \mathrm{L}$ of $10 \mu \mathrm{M}$ of each primer, and $1 \mu \mathrm{L}$ of the extracted gDNA. The primers used to amplify regions of LSU rDNA were DIR (5-ACCCGCTGAATTTAAGCATA-3) (Scholin et al. 1994), 28-1483R (5-GCTACTACCACCAAGATCTGC-3) (Daugbjerg et al. 2000), and LSUB (5-ACGAACGATTTGCACGTCAG-3) (Litaker et al. 2003). The gDNA was amplified in an AllInOneCycler (Bioneer, Daejeon, Korea) under the following conditions: $2 \mathrm{~min}$ at $95^{\circ} \mathrm{C}$ for initial denaturation, 38 cycles of $40 \mathrm{~s}$ at $95^{\circ} \mathrm{C}, 30 \mathrm{~s}$ at the annealing temperature, and $1 \mathrm{~min}$ at $72^{\circ} \mathrm{C}$, with a final extension of $5 \mathrm{~min}$ at $72^{\circ} \mathrm{C}$. The universal $l c f$ primers for amplifying the $l c f$ of dinoflagellates were used: LcfUniCHF3 (5'-TCCAGGTTGCACGCTTCGA-3') (Baker et al. 2008) and LcfUniCHR4 (5'-GGGTCTTGTCGCCGTACTCAAA-3') (Baker et al. 2008). These primer sets (LcfCHF3 and LcfCHR4) targeted the $l c f \mathrm{~N}$-terminal region, which is more diverse than the central regions (Baker et al. 2008). Polymerase chain reactions (PCRs) were performed under the following conditions: $5 \mathrm{~min}$ at $95^{\circ} \mathrm{C}$ for initial denaturation, 35 cycles of $45 \mathrm{~s}$ at $95^{\circ} \mathrm{C}, 30 \mathrm{~s}$ at $62^{\circ} \mathrm{C}$ and $45 \mathrm{~s}$ at $68^{\circ} \mathrm{C}$, and a final extension at $68^{\circ} \mathrm{C}$ for $5 \mathrm{~min}$.

The PCR products were purified using an AccuPrep DNA Purification Kit (Bioneer), and sequencing was performed using an ABI 3730XL DNA Analyzer (Applied Biosystems, Foster City, CA, USA).

\section{Phylogenetic analysis}

To explore the phylogenetic relationships of the bioluminescent Alexandrium species, revealed in the present study or in previous studies, the sequences of the LSU rDNA region of the Alexandrium species were aligned using the software MEGA v4 (Tamura et al. 2007), including sequences obtained from GenBank. Maximum likelihood (ML) analysis of the region was conducted using the program RAxML 7.0.3, with the general tIme reversible plus gamma (GTR + GAMMA) model (Stamatakis 2006). Furthermore, 200 independent tree inferences were used to identify the best tree. The ML bootstrap values were determined using 1,000 replicates.

To investigate any differences in the phylogenetic trees based on the LSU rDNA region and $l c f$ of the individual Alexandrium species, the $l c f$ sequences of the six Alexandrium species obtained in the present study and the five Alexandrium species available in GenBank were aligned. Protoceratium reticulatum was added because it formed a clade with A. pohangense, and Gonyaulax spinifera was added because it was positioned as a base of an Alexandrium clade. Lingulodinium polyedra was added as an outgroup. ML analysis of the region was conducted as described previously.

Bayesian analysis was conducted using MrBayes v.3.1 (Huelsenbeck and Ronquist 2001, Ronquist and Huelsenbeck 2003) with the default GTR + G + I model to determine the best available model for the data. For all sequence regions, four independent Markov chain Monte Carlo runs were performed simultaneously until the average standard deviation of split frequencies reached $<0.01$. The trees were sampled every 1,000 generations. To ensure likelihood convergence, the first 1,000 trees were discarded as burn-ins. Five million generations of LSU rDNA and three million generations of the $l c f$ of $A l$ exandrium species were run in MrBayes, and at least two million generations were saved for each tree reconstruction. The parameters were as follows for assumed nucleotide frequencies of LSU rDNA: substitution rate matrix with A-C substitution $=0.106, \mathrm{~A}-\mathrm{G}$ substitution $=0.236$, A-T substitution $=0.103, \mathrm{C}-\mathrm{G}$ substitution $=0.043, \mathrm{C}-\mathrm{T}$ substitution $=0.416$, G-T substitution $=0.095$; the proportion of sites assumed to be invariable $=0.051$; and the rate for variable sites assumed to follow a gamma distribution with shape parameter $=1.075$. For the assumed nucleotide frequencies of the $l c f$, parameters were: substitution rate matrix with $\mathrm{A}-\mathrm{C}$ substitution $=0.090, \mathrm{~A}-\mathrm{G}$ substitution $=0.255$, A-T substitution $=0.071, \mathrm{C}-\mathrm{G}$ substitution $=0.074, \mathrm{C}-\mathrm{T}$ substitution $=0.424$, and $\mathrm{G}-\mathrm{T}$ sub- 

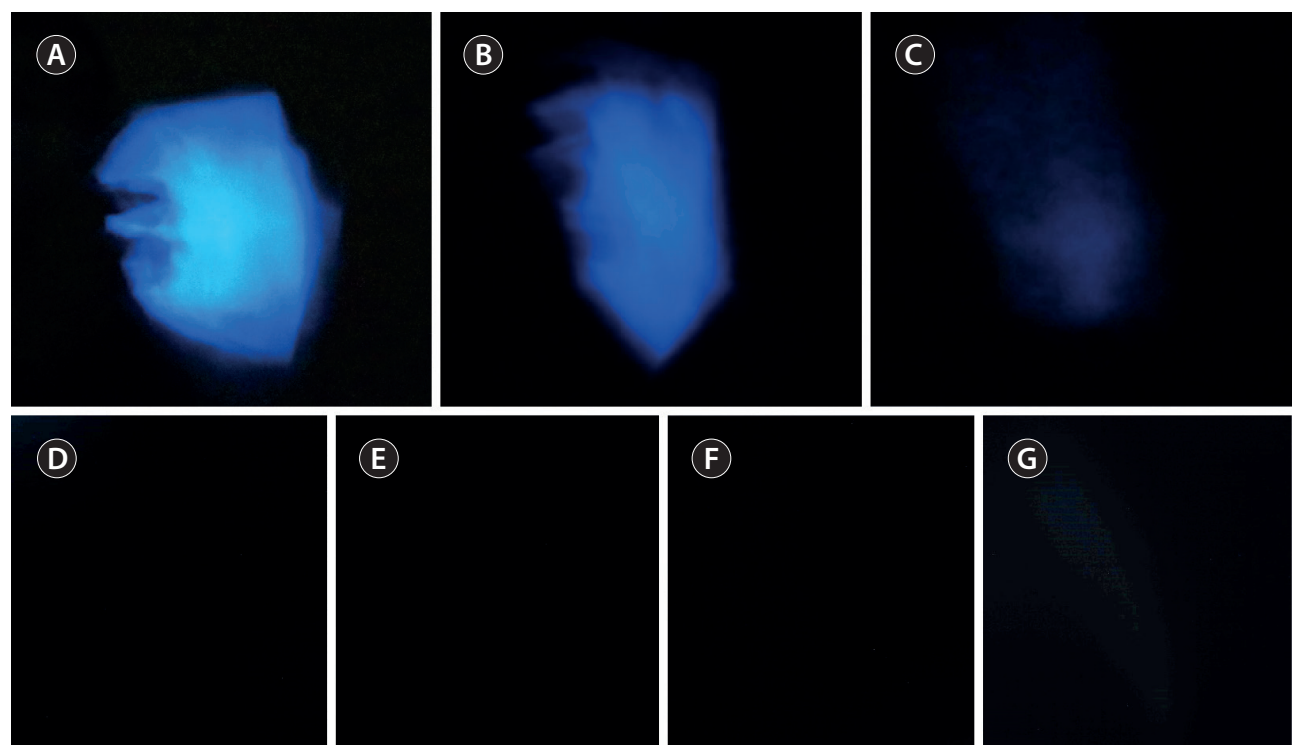

Fig. 1. Photographs of bioluminescence showing the bioluminescent capability of the Alexandrium species tested in the present study. A 250 $\mathrm{mL}$ culture flask containing a dense culture of each species in the late exponential stage was shaken by hand. (A) Alexandrium mediterraneum AMYS1807 (30,000 cells mL $\left.{ }^{-1}\right)$. (B) Alexandrium pohangense APPH1409 $\left(2,000\right.$ cells mL $\left.{ }^{-1}\right)$. (C) Alexandrium tamutum ATSH1609 (10,000 cells mL $\left.{ }^{-1}\right)$. (D) Alexandrium andersonii CCMP2222 (7,000 cells mL $\left.L^{-1}\right)$. (E) Alexandrium hiranoi NIES-3611 (1,000 cells mL $\left.{ }^{-1}\right)$. (F) Alexandrium pseudogonyaulax KSUDinoB4 $\left(1,000\right.$ cells $\left.\mathrm{mL}^{-1}\right)$. (G) Alexandrium insuetum $\mathrm{CCMP}^{2} 282\left(30,000\right.$ cells $\left.\mathrm{mL}^{-1}\right)$.

stitution $=0.086$; the proportion of sites assumed to be invariable $=0.391$; and the rate for variable sites assumed to follow a gamma distribution with shape parameter = 54.594. Moreover, the assumed nucleotide frequencies of LSU rDNA comprised the sequences of the Alexandrium species belonging to the lcf phylogeny, substitution rate matrix with $\mathrm{A}-\mathrm{C}$ substitution $=0.120, \mathrm{~A}-\mathrm{G}$ substitution $=$ 0.228 , A-T substitution $=0.089, \mathrm{C}-\mathrm{G}$ substitution $=0.066$, $\mathrm{C}-\mathrm{T}$ substitution $=0.395$, and $\mathrm{G}-\mathrm{T}$ substitution $=0.101$; the proportion of sites assumed to be invariable $=0.041$; and the rate for variable sites assumed to follow a gamma distribution with shape parameter $=1.353$.

\section{Statistical analysis}

To test whether the $\mathrm{BL}_{\text {Int200s }}$ or $\mathrm{BL}_{\text {Max }}$ of eight Alexandrium species differ from one another, univariate analyses were performed. Normality and homogeneity of variance were tested using Shapiro-Wilk's $W$ and Levene's tests, respectively. A parametric one-way analysis of variance (ANOVA) was performed. If the data did not satisfy the homogeneity assumption, Welch's one-way ANOVA and the Games-Howell post-hoc test were performed (Welch 1947, Games and Howell 1976). When the data did not meet the normality assumption, a nonparametric Kruskal-Wallis test and Mann-Whitney U test with Bonferroni correction $(\mathrm{p}<0.05)$ were conducted (Mann and Whit- ney 1947, Kruskal and Wallis 1952, Dunn 1961). Spearman's rank correlation coefficient was used to examine relationships between the variables equivalent spherical diameter (ESD) of bioluminescence species, maximum swimming speed, maximum growth rate, $\mathrm{BL}_{\text {Int200s }}$, and $\mathrm{BL}_{\mathrm{Max}}$. Statistical analyses were performed using SPSS ver. 25.0 (IBM-SPSS Inc., Armonk, NY, USA).

\section{RESULTS}

\section{Bioluminescence capability of Alexandrium species}

Among the seven Alexandrium species tested, A. mediterraneum AMYS1807, A. pohangense APPH1409, and A. tamutum ATSH1609 had bioluminescent capability, whereas A. andersonii CCMP2222, A. hiranoi NIES-3611, A. insuetum CCMP2082, and A. pseudogonyaulax KSUDinoB4 did not (Table 2, Fig. 1).

\section{Position of bioluminescent Alexandrium species in a phylogenetic tree based on the LSU rDNA sequences}

In a phylogenetic tree based on the LSU rDNA sequences, all 10 bioluminescent Alexandrium species 
were positioned in all four large clades (Fig. 2). Of the 10 species, six (A. affine, A. catenella, A. fraterculus, A. mediterraneum, A. pacificum, and A.tamarense) belonged to a large clade (called bioluminescence clade I, BLClade I), whereas two species (A. ostenfeldii and A.tamutum) belonged to another large clade (BLClade II). However, $A$. pohangense (BLClade III) and A. monilatum (BLClade IV) belonged to other large clades.

\section{Phylogenetic tree based on the Icf sequences}

In phylogenetic trees based on the lcf and LSU rDNA sequences, the positions of nine bioluminescent Alexandrium species were the same, with the exception of A. pohangense (Fig. 3). In the phylogenetic tree based on the $l c f$ sequences, A. pohangense formed a separate clade with Protoceratium reticulatum (Fig. 3A); however, in the phylogenetic tree based on the LSU rDNA sequences, $A$. pohangense was positioned inside a large Alexandrium clade (Fig. 3B).

\section{Bioluminescence intensity of eight Alexandrium species}

The $\mathrm{BL}_{\mathrm{Int200s}}$ of eight Alexandrium species ranged from $0.02 \times 10^{4}$ to $32.2 \times 10^{4} \mathrm{RLU}$ cell $^{-1}$ (Table 2, Fig. 4A); that of A. ostenfeldii was the highest, whereas that of A. tamarense was the lowest. The $\mathrm{BL}_{\text {Int20os }}$ values of the eight $A l$ exandrium species were significantly different (Welch's ANOVA, $\mathrm{F}_{7,9.06}=67.15, \mathrm{p}<0.01$ ) and were divided into three subsets (Games-Howell post-hoc test, $\mathrm{p}<0.05$ ) (Fig. $4 \mathrm{~A})$. The $\mathrm{BL}_{\mathrm{Max}}$ of the eight Alexandrium species ranged from $0.01 \times 10^{4}$ to $10.3 \times 10^{4} \mathrm{RLU}$ cell ${ }^{-1} \mathrm{~s}^{-1}$ (Table 2, Fig. 4B). The $\mathrm{BL}_{\mathrm{Max}}$ values of the eight Alexandrium species were significantly different (Kruskal-Wallis test, $\mathrm{H}_{7}=28.80, \mathrm{p}<$ 0.01 ), and the Mann-Whitney U test with Bonferroni correction $(\mathrm{p}<0.05)$ revealed that the $\mathrm{BL}_{\mathrm{Max}}$ values of the $A l$ exandrium species were divided into three subsets (Fig. $4 \mathrm{~B})$.

\section{DISCUSSION}

\section{Bioluminescence capability}

The present study explored the bioluminescence capability of seven Alexandrium species (A. andersonii, A. hiranoi, A. insuetum, A. pseudogonyaulax, A. mediterraneum, A. pohangense, and A. tamutum). Previously, the bioluminescence capability of nine Alexandrium species was explored. Thus, the bioluminescence capability of a total of 16 Alexandrium species, almost half the 33 formally described Alexandrium species, has now been explored. It is worthwhile to investigate the bioluminescence capability of the remaining 17 Alexandrium species.

The present study is the first to examine bioluminescence in A. mediterraneum, A. pohangense, and A. tamutum. Previously, eight Alexandrium species were reported to be bioluminescent; thus, a total of 11 Alexandrium species, $33 \%$ of the 33 formally described Alexandrium species, have been revealed to be bioluminescent. Before the present study was conducted, $90 \%$ of the tested Alexandrium species (eight of nine tested species) were

Table 2. Mean 200-second-integrated bioluminescence intensity per cell (BLInt200s, $\times 10^{4} \mathrm{RLU}_{\text {cell }}{ }^{-1} \pm$ standard error) and mean maximum bioluminescence intensity per cell per second ( $B L_{M a x} \times 10^{4} \mathrm{RLU}_{\text {cell }} \mathrm{s}^{-1} \pm$ standard error) of the 13 Alexandrium species tested in the present study

\begin{tabular}{|c|c|c|c|c|c|}
\hline Species & Strain name & ESD & BC & $\mathrm{BL}_{\text {Int200s }}$ & $\mathrm{BL}_{\operatorname{Max}}$ \\
\hline Alexandrium andersonii & CCMP2222 & 14.9 & $x$ & $0.00 \pm 0.0$ & \\
\hline A. minutum & ССМР1888 & 20.4 & $\times$ & $0.00 \pm 0.0$ & \\
\hline A. insuetum & ССMP2082 & 26.4 & $x$ & $0.00 \pm 0.0$ & \\
\hline A. pseudogonyaulax & KSUDinoB4 & 35.4 & $x$ & $0.00 \pm 0.0$ & \\
\hline A. hiranoi & NIES-3611 & 40.0 & $x$ & $0.00 \pm 0.0$ & \\
\hline A. tamutum & ATSH1609 & 22.5 & ० & $1.54 \pm 0.1$ & $0.19 \pm 0.1$ \\
\hline A. ostenfeldii & NIES-4274 & 29.8 & ० & $32.2 \pm 4.5$ & $10.3 \pm 1.3$ \\
\hline A. pacificum & KSUDinoE4 & 30.3 & ० & $1.55 \pm 0.1$ & $0.34 \pm 0.1$ \\
\hline A. affine & AATA1308 & 31.4 & ० & $9.23 \pm 2.1$ & $2.80 \pm 0.7$ \\
\hline A. pohangense & APPH1409 & 32.0 & o & $19.2 \pm 2.0$ & $2.75 \pm 0.5$ \\
\hline A. fraterculus & AFYS1309 & 32.3 & ० & $12.7 \pm 2.1$ & $4.53 \pm 0.9$ \\
\hline A. mediterraneum & AMYS1807 & 33.0 & ○ & $0.70 \pm 0.1$ & $0.14 \pm 0.0$ \\
\hline A.tamarense & CCMP115 & 34.6 & ० & $0.02 \pm 0.0$ & $0.01 \pm 0.0$ \\
\hline
\end{tabular}

$\mathrm{RLU}$, relative luminescence unit; $\mathrm{ESD}$, equivalent spherical diameter $(\mu \mathrm{m}) ; \mathrm{BC}$, bioluminescence capability; $\circ$, bioluminescent; $\times$, not bioluminescent. 


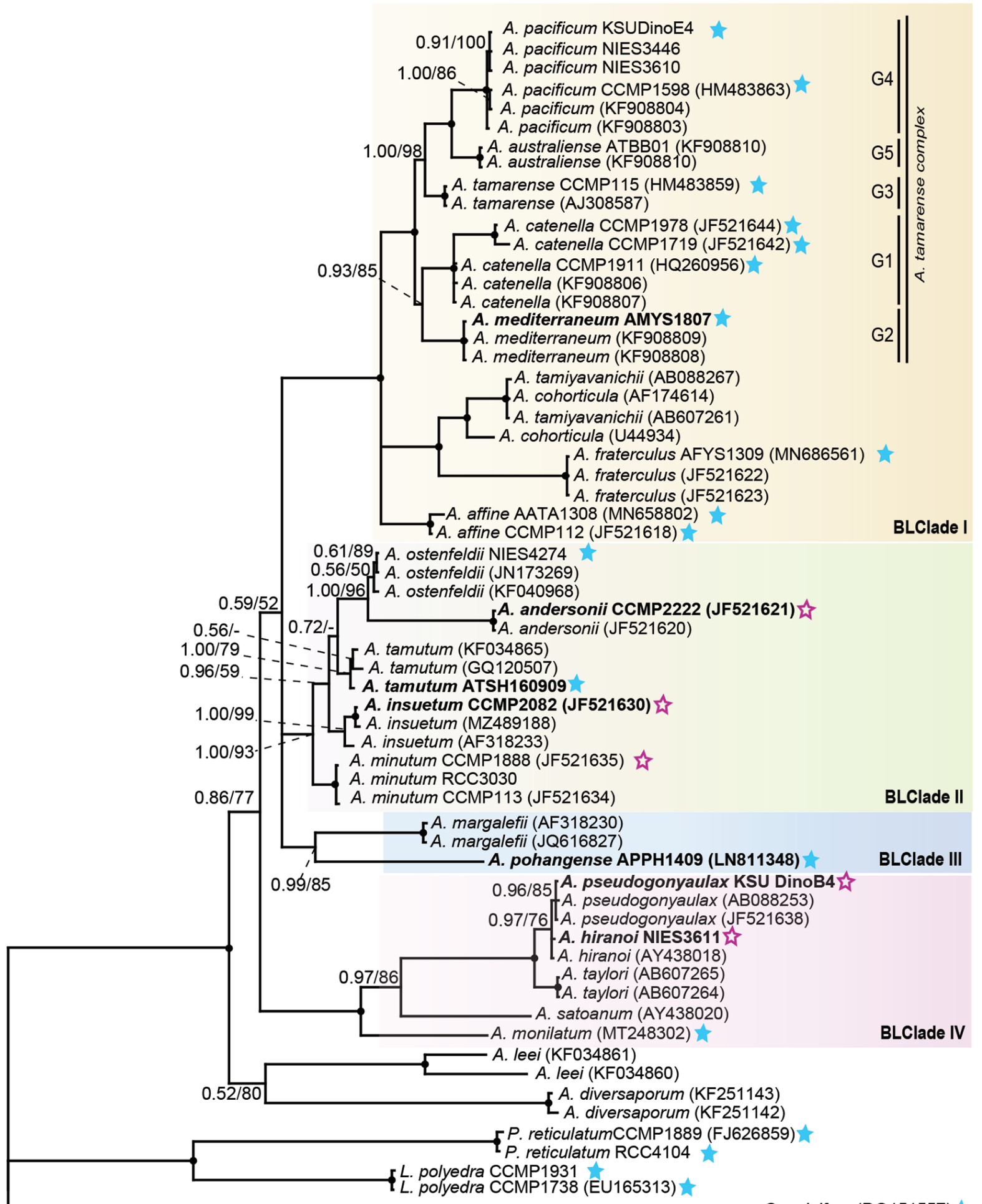

0.1

Fig. 2. Consensus Bayesian tree of nuclear large subunit ribosomal DNA region (based on 890 bp aligned position), using the GTR $+\mathrm{G}+\mathrm{I}$ model. The bioluminescent dinoflagellates Lingulodinium polyedra, Protoceratium reticulatum, and Gonyaulax spinifera were used as the outgroups. The numbers above the branches indicate the Bayesian posterior probability ( $\geq 0.5$, left) and maximum likelihood bootstrap values ( $\geq 50 \%$, right), and solid black circles indicate full support (1.0 and 100\%). Bioluminescent strains are indicated by a blue closed star, whereas nonbioluminescent strains are indicated by a purple open star. The strains tested in the present study are written in bold. 

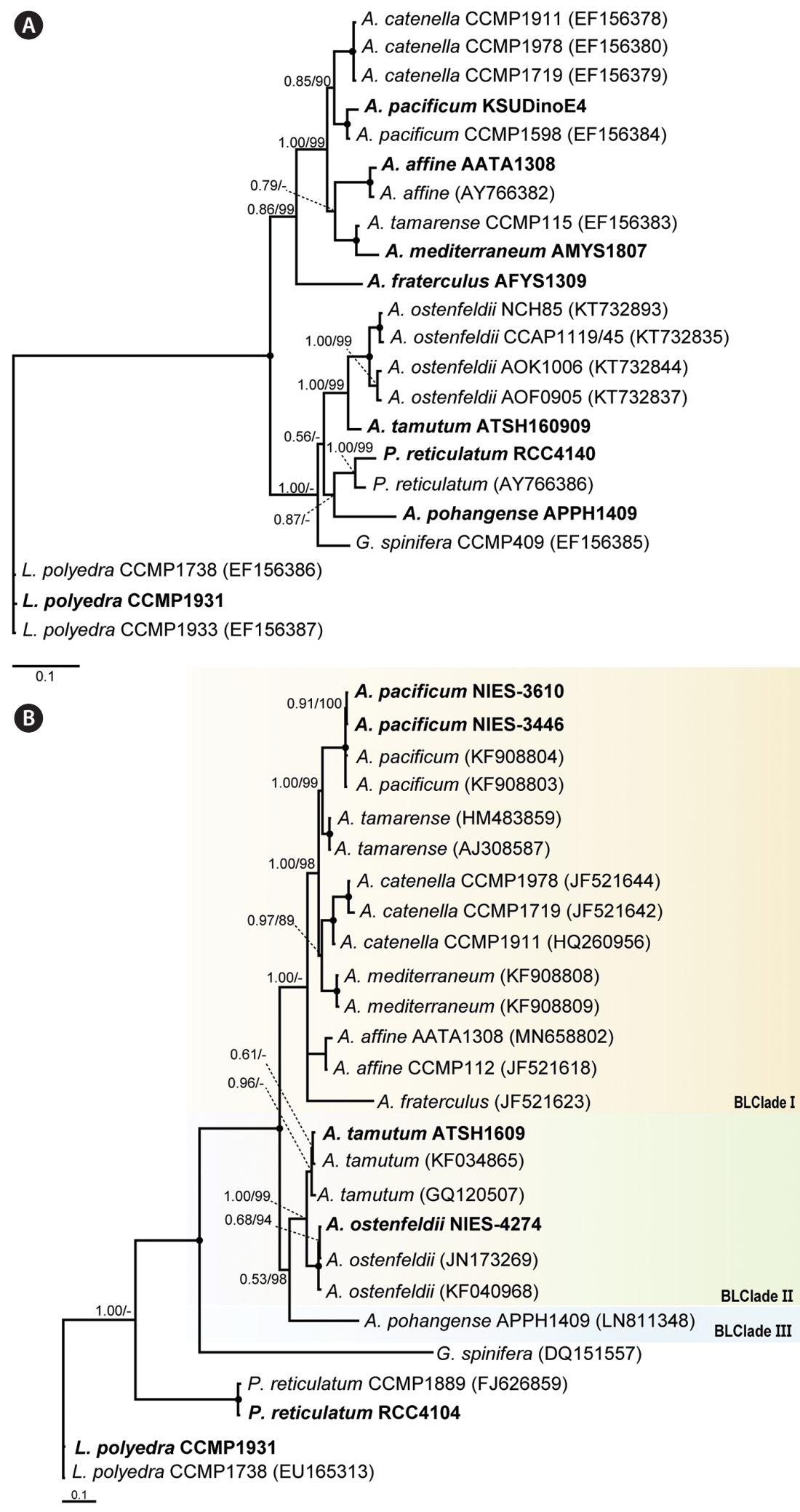

Fig. 3. Consensus Bayesian tree, based on 498 bp aligned position of nuclear luciferase gene (Icf) (A) and based on 890 bp aligned position of the large subunit ribosomal DNA (B), using the GTR $+\mathrm{G}+$ I model and Lingulodinium polyedra as the outgroup. The numbers above the branches indicate the Bayesian posterior probability $(\geq 0.5$, left) and maximum likelihood bootstrap values ( $\geq 50 \%$, right), and solid black circles indicate full support (1.0 and 100\%). The sequences obtained in the present study are in boldface. 

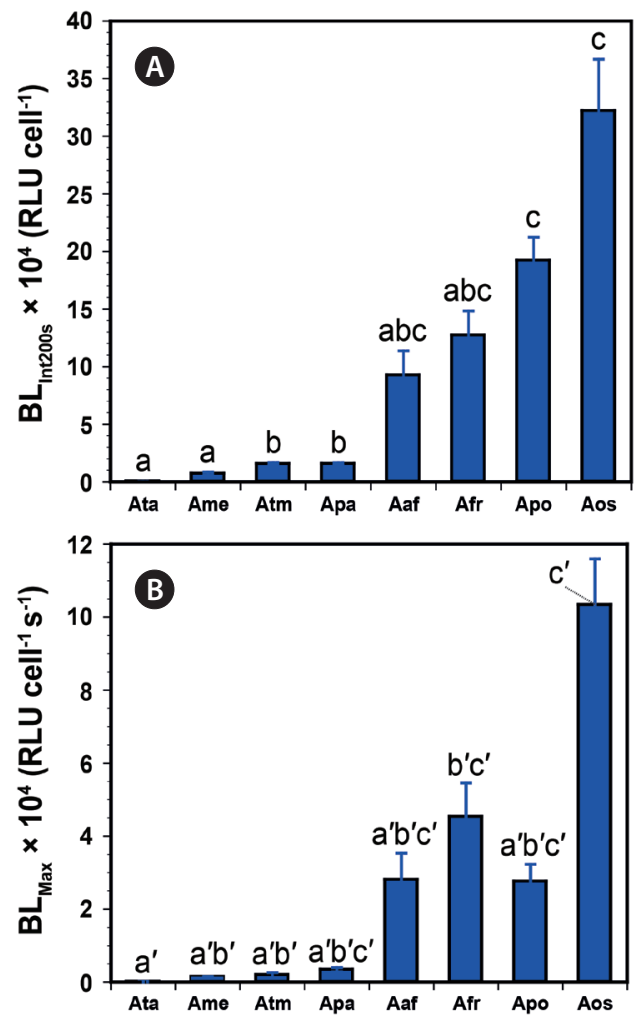

Fig. 4. Bioluminescence intensity of each Alexandrium species. (A) The mean 200-second-integrated bioluminescence intensity per cell (BL Int200s). Significantly different subsets of the Alexandrium species based on Games-Howell post-hoc tests $(p<0.05)$ of Welch's ANOVA: (a) Alexandrium tamarense (Ata) and A. mediterraneum (Ame); (b) A. tamutum (Atm) and A. pacificum (Apa); (abc) A. affine (Aaf) and $A$. fraterculus (Afr); (c) A. ostenfeldii (Aos) and A. pohangense (Apo). (B) The mean maximum bioluminescence intensity per cell per second $\left(B L_{\text {Max }}\right)$. Significantly different subsets of Alexandrium species based on the Bonferroni post-hoc test $(p<0.05)$ of Kruskal-Wallis test: $\left(a^{\prime}\right)$ Ata; (a'b') Ame and Atm; (a'b'c') Apa, Aaf, and Apo; (b'c') Afr; ( $\left.c^{\prime}\right)$ Aos. $R L U$, relative luminescence unit. Values represent the treatment means \pm standard error $(n=4)$.

known to be bioluminescent. However, the addition of our data shows that only $69 \%$ of tested Alexandrium species were bioluminescent. Thus, it is incorrect to assert that as a rule, Alexandrium species are bioluminescent; in fact, bioluminescence capability of these organisms is species-dependent.

\section{Position of bioluminescent Alexandrium species in a phylogenetic tree based on the LSU rDNA sequences}

In a phylogenetic tree based on the LSU rDNA sequences, six of 10 bioluminescent Alexandrium species belonged to a large clade (BLClade I), although the 10 bioluminescent Alexandrium species spanned four large clades (BLClade I-IV). In BLClade I, all Alexandrium species are known to be bioluminescent, except for $A$. australiense, A. cohorticula, and A. tamiyavanichii, whose bioluminescence capability has not yet been tested. Thus, it is worthwhile to explore the bioluminescence capability of these three species to test the hypothesis that all Alexandrium species in BLClade I are bioluminescent.

In BLClade I, A. affine AAV1, A. catenella CCMP1719, A. pacificum CCMP1598, and A. tamarense UW2C are known to be toxic, whereas A. fraterculus AF0307MIE01 and $A$. mediterraneum SZN01 are known to be nontoxic (Higman et al. 2001, Nguyen-Ngoc 2004, Orr et al. 2011, John et al. 2014, Eckford-Soper et al. 2016, Subong et al. 2017, Blossom et al. 2019). Both bioluminescence and toxicity are tools for anti-predation (Esaias and Curl 1972, Colin and Dam 2003, Bergkvist et al. 2008, Wohlrab et al. 2010, Lindström et al. 2017). Although all six Alexandrium species in BLClade I were bioluminescent, the toxicity status of these six species was split (Table 3, Fig. 5). Thus, bioluminescence is likely to be a primary defense tool and toxicity as a supplementary tool in this clade. Furthermore, A. catenella, A. pacificum CCMP3434, and A. tamarense are known to be mixotrophic, whereas $A$. affine CCMP112, A. fraterculus AFYS1309, and A. mediterraneum CCMP3433 are not mixotrophic (Table 3, Fig. 5) (Jeong et al. 2005, Lee et al. 2016, Lim et al. 2019). Thus, the acquisition of a mixotrophic capability in the six Alexandrium species in BLClade I may have occurred later than that of bioluminescence capability. However, further studies are needed to confirm the timing of the acquisition of a mixotrophic and bioluminescence capability in Alexandrium species.

\section{Phylogenetic tree based on Icf sequences}

The positions of nine bioluminescent Alexandrium species in the phylogenetic trees based on the lcf sequences were almost the same as those in the phylogenetic trees based on the LSU rDNA. This congruence is also shown in internal transcribed spacer and small subunit rDNA phylogenies (Baker et al. 2008, Valiadi et al. 2012, Le Tortorec et al. 2016). Thus, the $l c f$ and ribosomal DNA may have coevolved. In the phylogenetic trees based on LSU rDNA sequences, $A$. pohangense was included in BLClade III. However, in the phylogenetic trees based on $l c f$ genes, A. pohangense formed a clade with $P$. reticulatum, separate from the other Alexandrium species, unlike in the phylogenetic trees based on LSU rDNA sequences. The sequences in the $l c f \mathrm{~N}$-terminal region of $A$. pohangense differed from those of $P$. reticulatum by 


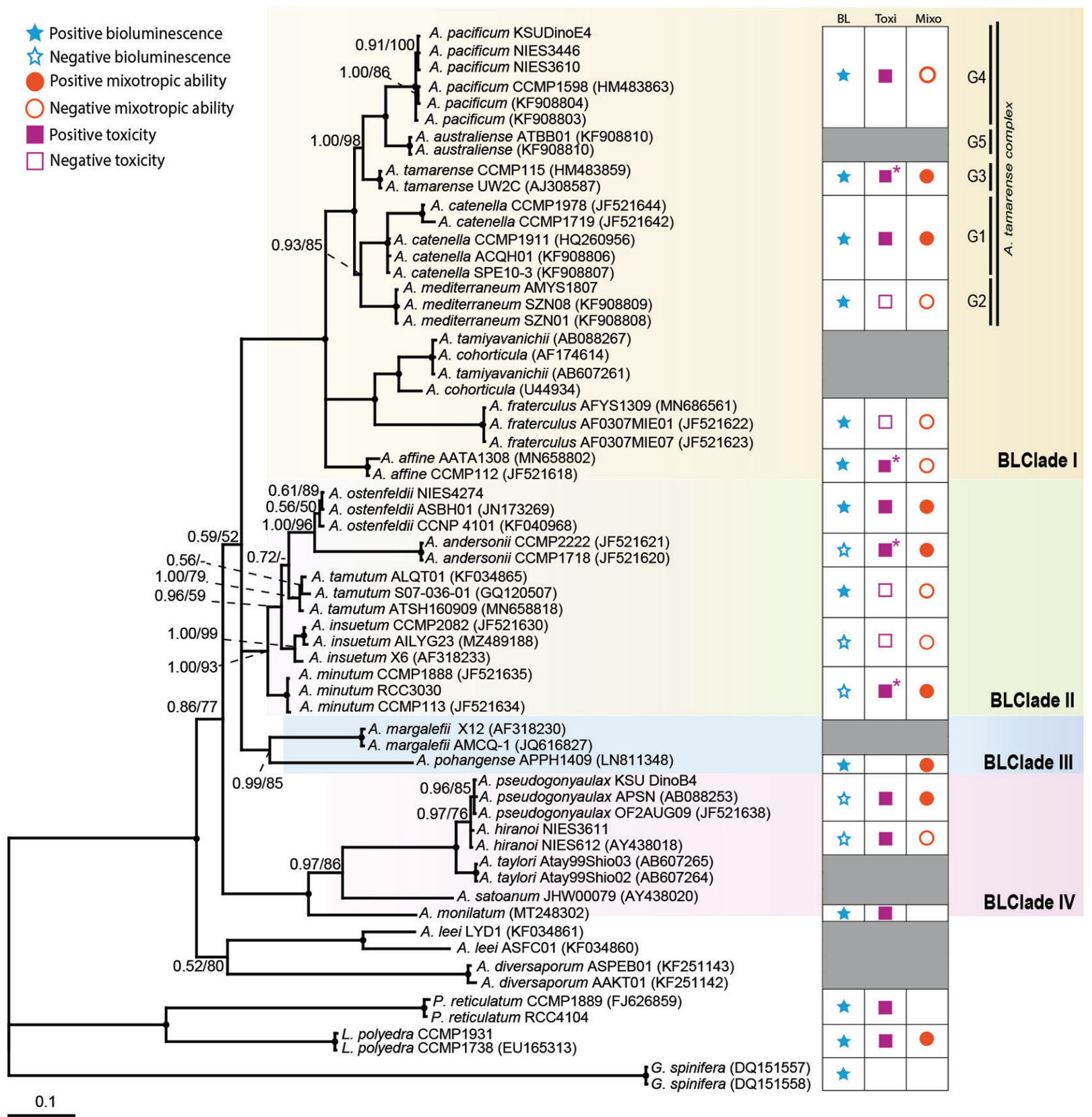

Fig. 5. Comparison of the presence (closed symbols) or absence (open symbols) of bioluminescent capacity (BL), toxicity (Toxi), and mixotrophic ability (Mixo) in the Consensus Bayesian tree of the nuclear large subunit ribosomal DNA region in Fig. 2. Asterisks indicate that some strains are toxic, whereas others are nontoxic (Prakash and Taylor 1966, Murakami et al. 1988, 1998, Jacobson and Anderson 1996, Satake et al. 1997, Draisci et al. 1999, Ciminiello et al. 2000, Higman et al. 2001, MacKenzie et al. 2004, Montresor et al. 2004, Nguyen-Ngoc 2004, Jeong et al. 2005, Lilly et al. 2005, Yoo et al. 2009, Orr et al. 2011, 2013, Blossom et al. 2012, 2017, John et al. 2014, Lim et al. 2015, 2019, Eckford-Soper et al. 2016, Lee et al. 2016, Subong et al. 2017, Murray et al. 2020).

41 bp (9.8\%) (GenBank accession No. AY766386), but they differed from the other Alexandrium species by 43-81 bp (10.3-19.3\%) (GenBank accession numbers listed in Fig. 3). Similarly, Valiadi et al. (2012) reported that the $l c f$ in the catalytic domains of A. monilatum (included in
BLClade IV of the phylogenetic tree based on LSU rDNA) was more similar to that of L. polyedra than that of Alexandrium species. Thus, it may not be surprising that $A$. pohangense forms a clade with $P$. reticulatum, rather than other Alexandrium species. 

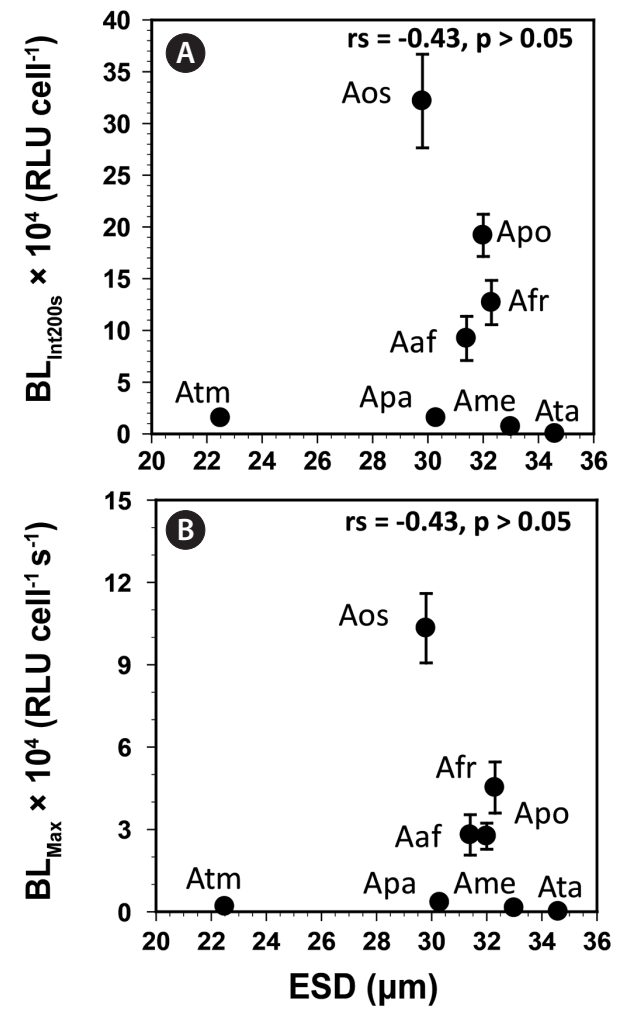

Fig. 6. Mean 200-second-integrated bioluminescence intensity per cell (BLint200s) $(A)$ and mean maximum bioluminescence intensity per cell per second $\left(B \mathrm{~L}_{\operatorname{Max}}\right)(\mathrm{B})$ of bioluminescent Alexandrium species as a function of cell size (equivalent spherical diameter [ESD], $\mu \mathrm{m}$ ), as described in Table 2 . The values represent the treatment means \pm standard error $(n=4)$. The Spearman correlation coefficient and $p$ value were described in the figures. Aaf, $A$. affine; Afr, A. fraterculus; Ame, A. mediterraneum; Aos, A. ostenfeldii; Apa, A. pacificum; Apo, A. pohangense; Ata, A. tamarense; Atm, A. tamutum.

\section{Bioluminescence intensity of eight Alexandrium species}

The results of the present study clearly showed that there were interspecific variations in the bioluminescence intensity of Alexandrium species. However, none of the $\mathrm{BL}_{\mathrm{Int} 200 \mathrm{~s}}$ or $\mathrm{BL}_{\mathrm{Max}}$ values of the Alexandrium species investigated in the present study were significantly correlated with the ESD (Fig. 6). Thus, other factors may affect the $\mathrm{BL}_{\text {Int200s }}$ or $\mathrm{BL}_{\text {Max }}$ of Alexandrium species. In addition, none of the $\mathrm{BL}_{\text {Int200s }}$ or $\mathrm{BL}_{\text {Max }}$ values of the Alexandrium species investigated in the present study were significantly correlated with the maximum growth rate (Fig. 7). However, when the maximum growth rate of $A$. tamarense was excluded, the $\mathrm{BL}_{\mathrm{Max}}$ of Alexandrium species was negatively correlated with the maximum growth rate (Spearman's rank correlation coefficient; rs $=-1.00$, $\mathrm{p}<0.01$ ). In general, the energy gained by a bioluminescent organism is used for reproduction or growth, respiration (swimming and metabolism), excretion, and bioluminescence. Thus, the bioluminescence intensity of bioluminescent organisms may be low if the growth rate is high.

None of the $\mathrm{BL}_{\text {Int200s }}$ or $\mathrm{BL}_{\text {Max }}$ values of the Alexandrium species investigated in the present study were significantly correlated with the maximum swimming speed (Fig. 8) (Spearman's rank correlation coefficient; $r s=-0.01$ and $-0.12, \mathrm{p}>0.05)$. However, the $\mathrm{BL}_{\text {Int20os }}$ and $\mathrm{BL}_{\mathrm{Max}}$ values of $A$. ostenfeldii were considerably greater than those of the other Alexandrium species. Therefore, A. ostenfeldii

Table 3. Comparison of bioluminescence capability (BC), mixotrophy, and toxicity of Alexandrium species

\begin{tabular}{|c|c|c|c|c|c|}
\hline Species & Strain & BC & Mixotrophy & Toxicity & Reference \\
\hline Alexandrium insuetum & CCMP2082 & $x$ & $x$ & $\times$ & Orr et al. (2013), Lim et al. (2019) \\
\hline A. minutum & CCMP1888 & $\times$ & ० & o & Jeong et al. (2005), Orr et al. (2011) \\
\hline A. andersonii & CCMP2222 & $\times$ & ○ & $x$ & Orr et al. (2011), Lee et al. (2016) \\
\hline A. pseudogonyaulax & KSUDinoB4 & $\times$ & $\mathrm{O}^{\mathrm{a}}$ & $\mathrm{O}^{\mathrm{a}}$ & Murakami et al. (1988), Blossom et al. $(2012,2017)$ \\
\hline A. hiranoi & NIES-3611 & $\times$ & $x^{\mathrm{a}}$ & $\circ$ & Murakami et al. (1998), Blossom et al. (2012) \\
\hline A. acatenella & & ○ & - & $\mathrm{O}^{\mathrm{a}}$ & Prakash and Taylor (1966), Esaias and Curl (1972) \\
\hline A. affine & CCMP112 & ○ & $\times$ & $\times$ & Orr et al. (2011), Lee et al. (2016) \\
\hline A. fraterculus & AFYS1309 & ○ & $\times$ & $x^{\mathrm{a}}$ & MacKenzie et al. (2004), Lee et al. (2016) \\
\hline A. catenella & CCMP1719 & ○ & $\mathrm{O}^{\mathrm{a}}$ & $\circ$ & Jeong et al. (2005), Orr et al. (2013), Lim et al. (2019) \\
\hline A. mediterraneum & AMYS1807 & ○ & $x^{\mathrm{a}}$ & $x^{\mathrm{a}}$ & John et al. (2014), Lim et al. (2019) \\
\hline A. monilatum & & ○ & - & $\mathrm{O}^{\mathrm{a}}$ & Sweeney (1963), MacKenzie et al. (2004) \\
\hline A. tamarense & CCMP115 & ○ & $\mathrm{O}^{\mathrm{a}}$ & $\times$ & Jeong et al. (2005), Orr et al. (2013), Lim et al. (2019) \\
\hline A. pacificum & KSUDinoE4 & ○ & $x^{\mathrm{a}}$ & $\mathrm{O}^{\mathrm{a}}$ & John et al. (2014), Lim et al. (2019), Murray et al. (2020) \\
\hline A. tamutum & ATSH1609 & ○ & $x^{a}$ & $x^{\mathrm{a}}$ & Montresor et al. (2004), Lim et al. (2019) \\
\hline A. ostenfeldii & NIES-4274 & ○ & $\mathrm{O}^{\mathrm{a}}$ & $\mathrm{O}^{\mathrm{a}}$ & Jacobson and Anderson (1996), Lilly et al. (2005) \\
\hline A. pohangense & APPH1409 & ○ & ○ & - & Lim et al. (2015) \\
\hline
\end{tabular}

The data were obtained from the present study and from the literature.

$\circ$, presence of bioluminescent capability, mixotrophic ability, or toxicity; $\times$, absence of bioluminescent capability, mixotrophic ability, or toxicity. aThe strains used for testing mixotrophic ability and toxicity differed from the strain used for testing bioluminescence. 

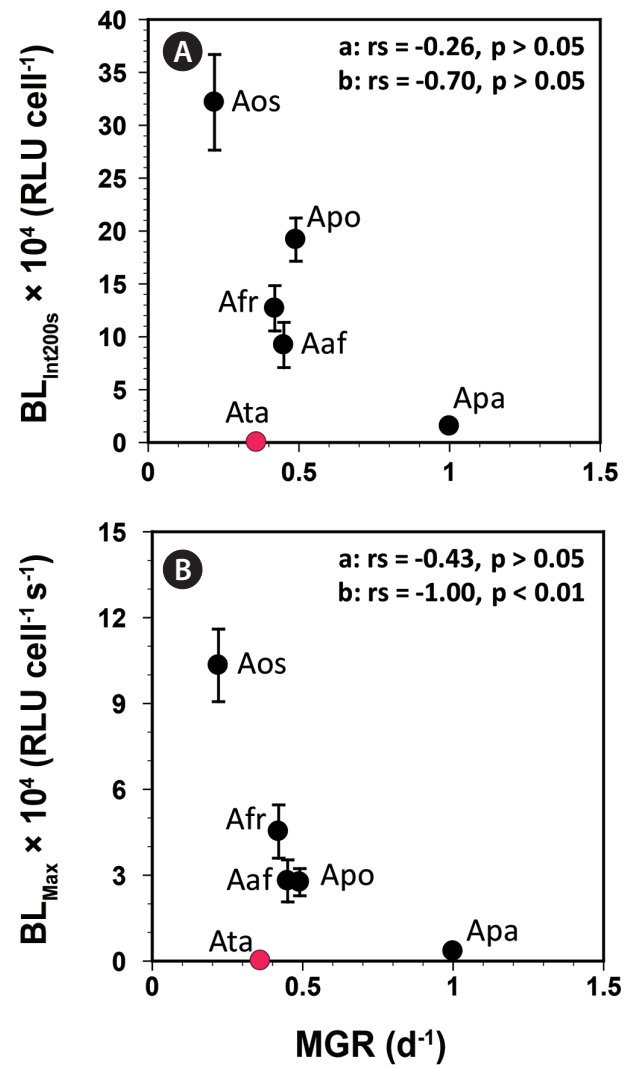

Fig. 7. Mean 200-second-integrated bioluminescence intensity per cell ( $\left(\mathrm{L}_{\text {Int200s }}\right)(\mathrm{A})$ and the mean maximum bioluminescence intensity per cell per second $\left(\mathrm{BL}_{\mathrm{Max}}\right)(\mathrm{B})$ of the bioluminescent Alexandrium species as a function of maximum growth rate (MGR; $\left.d^{-1}\right)$. Values represent the treatment means \pm standard error $(n=4)$. a: the Spearman correlation coefficient and $p$-value of all species. b: the Spearman correlation coefficient and $\mathrm{p}$-value of all species except for A. tamarense (red circle). Aaf, A. affine; Afr, A. fraterculus; Aos, A. ostenfeldii; Apa, A. pacificum; Apo, A. pohangense; Ata, A. tamarense. MGR data were obtained from Gu (2011), Laabir et al. (2011), Lim et al. (2015), Bill et al. (2016), and Lee et al. (2019).

may spend less energy on swimming and may demonstrate notably higher $\mathrm{BL}_{\text {Int20os }}$ or $\mathrm{BL}_{\text {Max }}$ values than other Alexandrium species.

The present study enhanced our knowledge of bioluminescence in Alexandrium. It is the first to report bioluminescence capability in A. mediterraneum, A. pohangense, and $A$. tamutum and to report lack of bioluminescence capability in A. andersonii, A. hiranoi, A. insuetum, and A. pseudogonyaulax. Furthermore, this is the first study to report the bioluminescence intensity of more than three species in one genus and to explore factors affecting differences in bioluminescence intensity. Moreover, our data revealed that phylogenetic trees based on the LSU rDNA and lcf sequences of Alexandrium species were consistent except for A. pohangense. The biolumi-
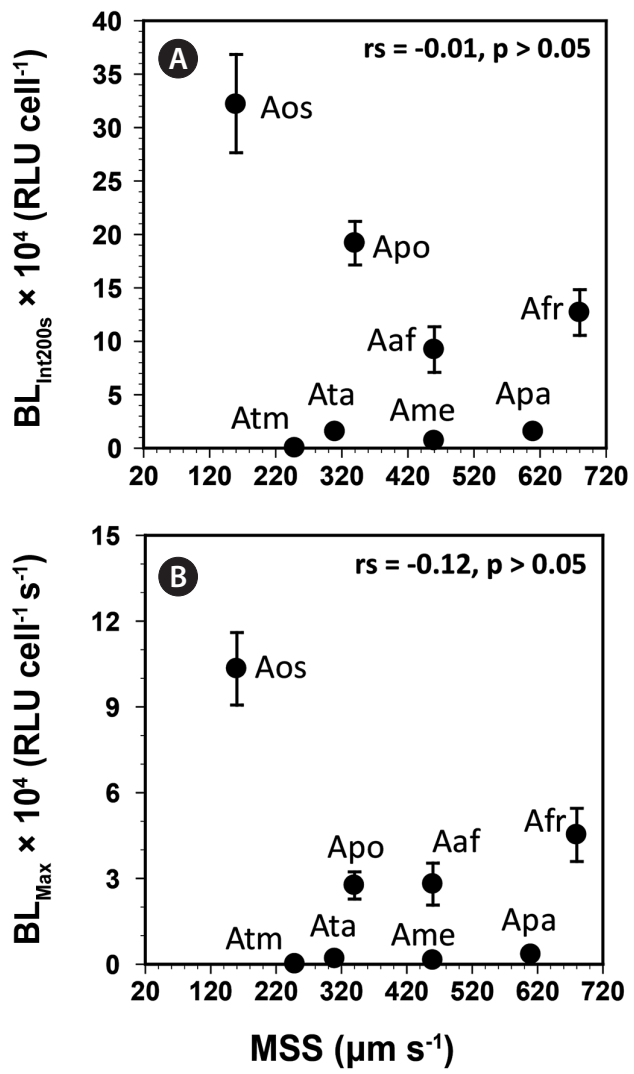

Fig. 8. Mean 200-second-integrated bioluminescence intensity per cell (BLint20os) $(A)$ and the mean maximum bioluminescence intensity per cell per second $\left(B L_{\text {Max }}\right)(B)$ of the bioluminescent Alexandrium species as a function of maximum swimming speed (MSS; $\mu \mathrm{m} \mathrm{s}^{-1}$ ). Values represent the treatment means \pm standard error $(n=4)$. The Spearman correlation coefficient and $\mathrm{p}$-value were described in the figures. Aaf, A. affine; Afr, A. fraterculus; Ame, A. mediterraneum; Aos, A. ostenfeldii; Apa, A. pacificum; Apo, A. pohangense; Ata, A. tamarense; Atm, A. tamutum. MSS data were obtained from Lewis et al. (2006), Lim et al. (2015, 2018), Lee et al. (2016), and Kang et al. (2018).

nescence capabilities of 17 Alexandrium species have not yet been explored and provide a rich opportunity for further studies of bioluminescence in Alexandrium species.

\section{ACKNOWLEDGEMENTS}

This research was supported by the National Research Foundation (NRF) funded by the Ministry of Science and ICT (NRF-2020M3F6A1110582; NRF-2021M3I6A1091272; 2021R1A2C1093379) and by the Useful Dinoflagellate program of Korea Institute of Marine Science and Technology Promotion (KIMST) funded by the Ministry of Oceans and Fisheries (MOF) award to HJJ. 


\section{CONFLICTS OF INTEREST}

The authors declare that they have no potential conflicts of interest.

\section{REFERENCES}

Anderson, D. M., Alpermann, T. J., Cembella, A. D., Collos, Y., Masseret, E. \& Montresor, M. 2012. The globally distributed genus Alexandrium: multifaceted roles in marine ecosystems and impacts on human health. Harmful Algae 14:10-35.

Baker, A., Robbins, I., Moline, M. A. \& Iglesias-Rodríguez, M. D. 2008. Oligonucleotide primers for the detection of bioluminescent dinoflagellates reveal novel luciferase sequences and information on the molecular evolution of this gene. J. Phycol. 44:419-428.

Bergkvist, J., Selander, E. \& Pavia, H. 2008. Induction of toxin production in dinoflagellates: the grazer makes a difference. Oecologia 156:147-154.

Biggley, W. H., Swift, E., Buchanan, R. J. \& Seliger, H. H. 1969. Stimulable and spontaneous bioluminescence in the marine dinoflagellates, Pyrodinium bahumense, Gonyaulax polyedra, and Pyrocystis lunula. J. Gen. Physiol. 54:96-122.

Bill, B. D., Moore, S. K., Hay, L. R., Anderson, D. M. \& Trainer, V. L. 2016. Effects of temperature and salinity on the growth of Alexandrium (Dinophyceae) isolates from the Salish Sea. J. Phycol. 52:230-238.

Blossom, H. E., Bædkel, T. D., Tillmann, U. \& Hansen, P. J. 2017. A search for mixotrophy and mucus trap production in Alexandrium spp. and the dynamics of mucus trap formation in Alexandrium pseudogonyaulax. Harmful Algae 64:51-62.

Blossom, H. E., Daugbjerg, N. \& Hansen, P. J. 2012. Toxic mucus traps: a novel mechanism that mediates prey uptake in the mixotrophic dinoflagellate Alexandrium pseudogonyaulax. Harmful Algae 17:40-53.

Blossom, H. E., Markussen, B., Daugbjerg, N., Krock, B., Norlin, A. \& Hansen, P. J. 2019. The cost of toxicity in microalgae: direct evidence from the dinoflagellate Alexandrium. Front. Microbiol. 10:1065.

Ciminiello, P., Fattorusso, E., Forino, M. \& Montresor, M. 2000. Saxitoxin and neosaxitoxin as toxic principles of Alexandrium andersoni (Dinophyceae) from the Gulf of Naples, Italy. Toxicon 38:1871-1877.

Colin, S. P. \& Dam, H. G. 2003. Effects of the toxic dinoflagellate Alexandrium fundyense on the copepod Acartia hudsonica: a test of the mechanisms that reduce inges- tion rates. Mar. Ecol. Prog. Ser. 248:55-65.

Cram, D. L. \& Schülein, F. H. 1974. Observations on surfaceshoaling Cape hake off South West Africa. ICES J. Mar. Sci. 35:272-275.

Cusick, K. D. \&Widder, E. A. 2014. Intensity differences in bioluminescent dinoflagellates impact foraging efficiency in a nocturnal predator. Bull. Mar. Sci. 90:797-811.

Cusick, K. D. \& Widder, E. A. 2020. Bioluminescence and toxicity as driving factors in harmful algal blooms: ecological functions and genetic variability. Harmful Algae 98:101850.

Cussatlegras, A. -S. \& Le Gal, P. 2007. Variability in the bioluminescence response of the dinoflagellate Pyrocystis lunula. J. Exp. Mar. Biol. Ecol. 343:74-81.

Daugbjerg, N., Hansen, G., Larsen, J. \& Moestrup, Ø. 2000. Phylogeny of some of the major genera of dinoflagellates based on ultrastructure and partial LSU rDNA sequence data, including the erection of three new genera of unarmoured dinoflagellates. Phycologia 39:302-317.

Draisci, R., Ferretti, E., Palleschi, L., Marchiafava, C., Poletti, R., Milandri, A., Ceredi, A. \& Pompei, M. 1999. High levels of yessotoxin in mussels and presence of yessotoxin and homoyessotoxin in dinoflagellates of the Adriatic Sea. Toxicon 37:1187-1193.

Dunn, O. J. 1961. Multiple comparisons among means. J. Am. Stat. Assoc. 56:52-64.

Eckert, R. 2015. Excitation and luminescence in Noctiluca miliaris. In Johnson, F. H. \& Haneda, Y. (Eds.) Bioluminescence in Progress. Princeton University Press, Princeton, NJ, pp. 269-300.

Eckford-Soper, L. K., Bresnan, E., Lacaze, J. -P., Green, D. H. \& Davidson, K. 2016. The competitive dynamics of toxic Alexandrium fundyense and non-toxic Alexandrium tamarense: the role of temperature. Harmful Algae 53:135-144.

Esaias, W. E. \& Curl, H. C. Jr. 1972. Effect of dinoflagellate bioluminescence on copepod ingestion rates. Limnol. Oceanogr. 17:901-906.

Esaias, W. E., Curl, H. C. Jr. \& Seliger, H. H. 1973. Action spectrum for a low intensity, rapid photoinhibition of mechanically stimulable bioluminescence in the marine dinoflagellates Gonyaulax catenella, G. acatenella, and G. tamarensis. J. Cell. Physiol. 82:363-372.

Fogel, M. \& Hastings, J. W. 1972. Bioluminescence: mechanism and mode of control of scintillon activity. Proc. Natl. Acad. Sci. U. S. A. 69:690-693.

Games, P. A. \& Howell, J. F. 1976. Pairwise multiple comparison procedures with unequal n's and/or variances: a Monte Carlo study. J. Educ. Stat. 1:113-125.

Gu, H. 2011. Morphology, phylogenetic position, and eco- 
physiology of Alexandrium ostenfeldii (Dinophyceae) from the Bohai Sea, China. J. Syst. Evol. 49:606-616.

Guillard, R. R. L. \& Hargraves, P. E. 1993. Stichochrysis immobilis is a diatom, not a chrysophyte. Phycologia 32:234236.

Guillard, R. R. L. \& Ryther, J. H. 1962. Studies of marine planktonic diatoms. I. Cyclotella nana Hustedt and Detonula confervacea (Cleve) Gran. Can. J. Microbiol. 8:229-239.

Guiry, M. D. \& Guiry, G. M. 2021. AlgaeBase. Available from: https://www.algaebase.org. Accessed Oct 10, 2021.

Haddock, S. H. D., Moline, M. A. \& Case, J. F. 2010. Bioluminescence in the sea. Annu. Rev. Mar. Sci. 2:443-493.

Hastings, J. W. \& Sweeney, B. M. 1957. The luminescent reaction in extracts of the marine dinoflagellate, Gonyaulax polyedra. J. Cell. Comp. Physiol. 49:209-225.

Higman, W. A., Stone, D. M. \& Lewis, J. M. 2001. Sequence comparisons of toxic and non-toxic Alexandrium tamarense (Dinophyceae) isolates from UK waters. Phycologia 40:256-262.

Huelsenbeck, J. P. \& Ronquist, F. 2001. MrBayes: Bayesian inference of phylogenetic trees. Bioinformatics 17:754755.

Jacobson, D. M. \& Anderson, D. M. 1996. Widespread phagocytosis of ciliates and other protists by marine mixotrophic and heterotrophic thecate dinoflagellates. J. Phycol. 32:279-285.

Jang, S. H. \& Jeong, H. J. 2020. Spatio-temporal distributions of the newly described mixotrophic dinoflagellate Yihiella yeosuensis (Suessiaceae) in Korean coastal waters and its grazing impact on prey populations. Algae 35:45-59.

Jeong, H. J., Kang, H. C., Lim, A. S., Jang, S. H., Lee, K., Lee, S. Y., Ok, J. H., You, J. H., Kim, J. H., Lee, K. H., Park, S. A., Eom, S. H., Yoo, Y. D. \& Kim, K. Y. 2021. Feeding diverse prey as an excellent strategy of mixotrophic dinoflagellates for global dominance. Sci. Adv. 7:eabe4214.

Jeong, H. J., Lim, A. S., Franks, P. J. S., Lee, K. H., Kim, J. H., Kang, N. S., Lee, M. J., Jang, S. H., Lee, S. Y., Yoon, E. Y., Park, J. Y., Yoo, Y. D., Seong, K. A., Kwon, J. E. \& Jang, T. Y. 2015. A hierarchy of conceptual models of red-tide generation: nutrition, behavior, and biological interactions. Harmful Algae 47:97-115.

Jeong, H. J., Lim, A. S., Lee, K., Lee, M. J., Seong, K. A., Kang, N. S., Jang, S. H., Lee, K. H., Lee, S. Y., Kim, M. O., Kim, J. H., Kwon, J. E., Kang, H. C., Kim, J. S., Yuh, W., Shin, K., Jang, P. K., Ryu, J. -H., Kim, S. Y., Park, J. Y. \& Kim, K. Y. 2017. Ichthyotoxic Cochlodinium polykrikoides red tides offshore in the South Sea, Korea in 2014: I. Temporal variations in three-dimensional distributions of red-tide organisms and environmental factors. Algae 32:101-130.
Jeong, H. J., Park, J. Y., Nho, J. H., Park, M. O., Ha, J. H., Seong, K. A., Jeng, C., Seong, C. N., Lee, K. Y. \& Yih, W. H. 2005. Feeding by red-tide dinoflagellates on the cyanobacterium Synechococcus. Aquat. Microb. Ecol. 41:131-143.

John, U., Litaker, R. W., Montresor, M., Murray, S., Brosnahan, M. L. \& Anderson, D. M. 2014. Formal revision of the Alexandrium tamarense species complex (Dinophyceae) taxonomy: the introduction of five species with emphasis on molecular-based (rDNA) classification. Protist 165:779-804.

Kang, H. C., Jeong, H. J., Kim, S. J., You, J. H. \& Ok, J. H. 2018. Differential feeding by common heterotrophic protists on 12 different Alexandrium species. Harmful Algae 78:106-117.

Kang, H. C., Jeong, H. J., Ok, J. H., You, J. H., Jang, S. H., Lee, S. Y., Lee, K. H., Park, J. Y. \& Rho, J. -R. 2019. Spatial and seasonal distributions of the phototrophic dinoflagellate Biecheleriopsis adriatica (Suessiaceae) in Korea: quantification using qPCR. Algae 34:111-126.

Kelly, M. G. 1968. The occurrence of dinoflagellate luminescence at Woods Hole. Biol. Bull. 135:279-295.

Krasnow, R., Dunlap, J. C., Taylor, W., Hastings, J. W., Vetterling, W. \& Gooch, V. 1980. Circadian spontaneous bioluminescent glow and flashing of Gonyaulax polyedra. J. Comp. Phvsiol. 138:19-26.

Kremp, A., Lindholm, T., Dreßler, N., Erler, K., Gerdts, G., Eirtovaara, S. \& Leskinen, E. 2009. Bloom forming Alexandrium ostenfeldii (Dinophyceae) in shallow waters of the Åland archipelago, Northern Baltic Sea. Harmful Algae 8:318-328.

Kruskal, W. H. \& Wallis, W. A. 1952. Use of ranks in one-criterion variance analysis. J. Am. Stat. Assoc. 47:583-621

Laabir, M., Jauzein, C., Genovesi, B., Masseret, E., Grzebyk, D., Cecchi, P., Vaquer, A., Perrin, Y. \& Collos, Y. 2011. Influence of temperature, salinity and irradiance on the growth and cell yield of the harmful red tide dinoflagellate Alexandrium catenella colonizing Mediterranean waters. J. Plankton Res. 33:1550-1563.

Lapota, D., Geiger, M. L., Stiffey, A. V., Rosenberger, D. E. \& Young, D. K. 1989. Correlations of planktonic bioluminescence with other oceanographic parameters from a Norwegian fjord. Mar. Ecol. Prog. Ser. 55:217-227.

Latz, M. I., Bovard, M., VanDelinder, V., Segre, E., Rohr, J. \& Groisman, A. 2008. Bioluminescent response of individual dinoflagellate cells to hydrodynamic stress measured with millisecond resolution in a microfluidic device. J. Exp. Biol. 211:2865-2875.

Latz, M. I. \& Jeong, H. J. 1996. Effect of red tide dinoflagellate diet and cannibalism on the bioluminescence of the heterotrophic dinoflagellates Protoperidinium spp. 
Mar. Ecol. Prog. Ser. 132:275-285.

Latz, M. I. \& Lee, A. O. 1995. Spontaneous and stimulated bioluminescence of the dinoflagellate Ceratocorys horrzda (Peridiniales). J. Phycol. 31:120-132.

Latz, M. I., Nauen, J. C. \& Rohr, J. 2004. Bioluminescence response of four species of dinoflagellates to fully developed pipe flow. J. Plankton Res. 26:1529-1546.

Le Tortorec, A. H., Tahvanainen, P., Kremp, A. \& Simis, S. G. H. 2016. Diversity of luciferase sequences and bioluminescence production in Baltic Sea Alexandrium ostenfeldii. Eur. J. Phycol. 51:317-327.

Lee, K. H., Jeong, H. J., Kang, H. C., Ok, J. H., You, J. H. \& Park, S. A. 2019. Growth rates and nitrate uptake of cooccurring red-tide dinoflagellates Alexandrium affine and $A$. fraterculus as a function of nitrate concentration under light-dark and continuous light conditions. Algae $34: 237-251$

Lee, K. H., Jeong, H. J., Kwon, J. E., Kang, H. C., Kim, J. H., Jang, S. H., Park, J.Y., Yoon, E. Y. \& Kim, J. S. 2016. Mixotrophic ability of the phototrophic dinoflagellates Alexandrium andersonii, A. affine, and A. fraterculus. Harmful Algae 59:67-81.

Lee, S. Y., Jeong, H. J., Ok, J. H., Kang, H. C. \& You, J. H. 2020. Spatial-temporal distributions of the newly described mixotrophic dinoflagellate Gymnodinium smaydae in Korean coastal waters. Algae 35:225-236.

Lewis, N. I., Xu, W., Jericho, S. K., Kreuzer, H. J., Jericho, M. H. \& Cembella, A. D. 2006. Swimming speed of three species of Alexandrium (Dinophyceae) as determined by digital in-line holography. Phycologia 45:61-70.

Lilly, E. L., Halanych, K. M. \& Anderson, D. M. 2005. Phylogeny, biogeography, and species boundaries within the Alexandrium minutum group. Harmful Algae 4:1004-1020.

Lim, A. S., Jeong, H. J., Kim, J. H., Jang, S. H., Lee, M. J. \& Lee, K. 2015. Mixotrophy in the newly described dinoflagellate Alexandrium pohangense: a specialist for feeding on the fast-swimming ichthyotoxic dinoflagellate Cochlodinium polykrikoides. Harmful Algae 49:10-18.

Lim, A. S., Jeong, H. J. \& Ok, J. H. 2019. Five Alexandrium species lacking mixotrophic ability. Algae 34:289-301.

Lim, A. S., Jeong, H. J., Ok, J. H. \& Kim, S. J. 2018. Feeding by the harmful phototrophic dinoflagellate Takayama tasmanica (Family Kareniaceae). Harmful Algae 74:19-29.

Lindström, J., Grebner, W., Rigby, K. \& Selander, E. 2017. Effects of predator lipids on dinoflagellate defense mechanisms-increased bioluminescence capacity. Sci. Rep. 7:13104.

Litaker, R. W., Vandersea, M. W., Kibler, S. R., Reece, K. S., Stokes, N. A., Steidinger, K. A., Millie, D. F., Bendis, B. J.,
Pigg, R. J. \& Tester, P. A. 2003. Identification of Pfiesteria piscicida (Dinophyceae) and Pfiesteria-like organisms using internal transcribed spacer-specific PCR assays. J. Phycol. 39:754-761.

Liu, L., Wilson, T. \& Hastings, J. W. 2004. Molecular evolution of dinoflagellate luciferases, enzymes with three catalytic domains in a single polypeptide. Proc. Natl. Acad. Sci. U. S. A. 101:16555-16560.

MacKenzie, L., de Salas, M., Adamson, J. \& Beuzenberg, V. 2004. The dinoflagellate genus Alexandrium (Halim) in New Zealand coastal waters: comparative morphology, toxicity and molecular genetics. Harmful Algae 3:71-92.

Mann, H. B. \& Whitney, D. R. 1947. On a test of whether one of two random variables is stochastically larger than the other. Ann. Math. Stat. 18:50-60.

Marcinko, C. L. J., Painter, S. C., Martin, A. P. \& Allen, J. T. 2013. A review of the measurement and modelling of dinoflagellate bioluminescence. Prog. Oceanogr. 109:117-129.

Martínez, A., Méndez, S. \& Fabre, A. 2016. First record of bioluminescence of Alexandrium fraterculus (dinoflagellate), in the Uruguayan coast, South Western Atlantic Ocean. Pan-Am. J. Aquat. Sci. 11:356-360.

McCapra, F. 1976. Chemical mechanisms in bioluminescence. Acc. Chem. Res. 9:201-208.

Miller, S. D., Haddock, S. H. D., Elvidge, C. D. \& Lee, T. F. 2005. Detection of a bioluminescent milky sea from space. Proc. Natl. Acad. Sci. U. S. A. 102:14181-14184.

Montresor, M., John, U., Beran, A. \& Medlin, L. K. 2004. Alexandrium tamutum sp. nov. (Dinophyceae): a new nontoxic species in the genus Alexandrium. J. Phycol. 40:398-411.

Murakami, M., Makabe, K., Yamaguchi, K., Konosu, S. \& Wälchli, M. R. 1988. Goniodomin A, a novel polyether macrolide from the dinoflagellate Goniodoma pseudogoniaulax. Tetrahedron Lett. 29:1149-1152.

Murakami, M., Okita, Y., Matsuda, H., Okino, T. \& Yamaguchi, K. 1998. From the dinoflagellate Alexandrium hiranoi. Phytochemistry 48:85-88.

Murray, S., John, U., Savela, H. \& Kremp, A. 2020. Alexandrium spp.: genetic and ecological factors influencing saxitoxin production and proliferation. In Botana, L. M., Louzao, M. C. \& Vilarino, N. (Eds.) Climate Change and Marine and Freshwater Toxins. Walter de Gruyter, Berlin, pp. 133-166.

Nguyen-Ngoc, L. 2004. An autecological study of the potentially toxic dinoflagellate Alexandrium affine isolated from Vietnamese waters. Harmful Algae 3:117-129.

Orr, R. J. S., Stüken, A., Murray, S. A. \& Jakobsen, K. S. 2013. Evolutionary acquisition and loss of saxitoxin biosynthesis in dinoflagellates: the second "core" gene, sxtG. 
Appl. Environ. Microbiol. 79:2128-2136.

Orr, R. J. S., Stüken, A., Rundberget, T., Eikrem, W. \& Jakobsen, K. S. 2011. Improved phylogenetic resolution of toxic and non-toxic Alexandrium strains using a concatenated rDNA approach. Harmful Algae 10:676-688.

Prakash, A. \& Taylor, F. J. R. 1966. A "red water" bloom of Gonyaulax acatenella in the Strait of Georgia and its relation to paralytic shellfish toxicity. J. Fish. Res. Board Can. 23:1265-1270.

Rohr, J., Latz, M. I., Fallon, S., Nauen, J. C. \& Hendricks, E. 1998. Experimental approaches towards interpreting dolphin-stimulated bioluminescence. J. Exp. Biol. 201: 1447-1460.

Ronquist, F. \& Huelsenbeck, J. P. 2003. MrBayes 3: Bayesian phylogenetic inference under mixed models. Bioinformatics 19:1572-1574.

Satake, M., MacKenzie, L. \&Yasumoto, T. 1997. Identification of Protoceratium reticulatum as the biogenetic origin of yessotoxin. Nat. Toxins 5:164-167.

Scholin, C. A., Herzog, M., Sogin, M. \& Anderson, D. M. 1994. Identification of group- and strain-specific genetic makers for globally distributed Alexandrium (Dinophyceae). II. Sequence analysis of a fragment of the LSU rRNA gene. J. Phycol. 30:999-1011.

Seliger, H. H., Biggley, W. H. \& Swift, E. 1969. Absolute values of photon emission from the marine dinoflagellates $P y$ rodinium bahamense, Gonyaulax polyedra and Pyrocystis lunula. Photochem. Photobiol. 10:227-232.

Shimomura, O. 2006. Bioluminescence: chemical principles and methods. World Scientific, Toh Tuck Link, $500 \mathrm{pp}$.

Stamatakis, A. 2006. RaxML-VI-HPC: maximum likelihoodbased phylogenetic analyses with thousands of taxa and mixed models. Bioinformatics 22:2688-2690.

Subong, B. J. J., Benico, G. A., Sulit, A. K. L., Mendoza, C. O., Cruz, L. J., Azanza, R. V. \& Jimenez, E. C. 2017. Toxicity and protein expression of Alexandrium species collected in the Philippine waters. Philipp. J. Sci. 146:425-436.

Sullivan, J. M. \& Swift, E. 1995. Photoenhancement of bioluminescence capacity in natural and laboratory populations of the autotrophic dinoflagellate Ceratium fusus (Ehrenb.) Dujardin. J. Geophys. Res. Oceans 100: 6565-6574.

Sweeney, B. M. 1963. Bioluminescent dinoflagellates. Biol. Bull. 125:177-181.

Sweeney, B. M. 1986. The loss of the circadian rhythm in photosynthesis in an old strain of Gonyaulax polyedra.
Plant Physiol. 80:978-981.

Swift, E., Biggley, W. H. \& Seliger, H. H. 1973. Species of oceanic dinoflagellates in the genera Dissodinium and $P y$ rocystis: interclonal and interspecific comparisons of the color and photon yield of bioluminescence. J. Phycol. 9:420-426.

Swift, E., Sullivan, J. M., Batchelder, H. P., Van Keuren, J., Vaillancourt, R. D. \& Bidigare, R. R. 1995. Bioluminescent organisms and bioluminescence measurements in the North Atlantic Ocean near latitude $59.5^{\circ} \mathrm{N}$, longitude $21^{\circ}$ W. J. Geophys. Res. Oceans 100:6527-6547.

Tamura, K., Dudley, J., Nei, M. \& Kumar, S. 2007. MEGA4: molecular evolutionary genetics analysis (MEGA) software version 4.0. Mol. Biol. Evol. 24:1596-1599.

Valiadi, M. \& Iglesias-Rodriguez, D. 2013. Understanding bioluminescence in dinoflagellates: how far have we come? Microorganisms 1:3-25.

Valiadi, M., Iglesias-Rodriguez, M. D. \& Amorim, A. 2012. Distribution and genetic diversity of the luciferase gene within marine dinoflagellates. J. Phycol. 48:826-836.

Von Dassow, P. \& Latz, M. I. 2002. The role of $\mathrm{Ca}^{2+}$ in stimulated bioluminescence of the dinoflagellate Lingulodinium polyedrum. J. Exp. Biol. 205:2971-2986.

Welch, B. L. 1947. The generalization of 'student's' problem when several different population variances are involved. Biometrika 34:28-35.

White, H. H. 1979. Effects of dinoflagellate bioluminescence on the ingestion rates of herbivorous zooplankton. J. Exp. Mar. Biol. Ecol. 36:217-224.

Widder, E. A. 2010. Bioluminescence in the ocean: origins of biological, chemical, and ecological diversity. Science 328:704-708.

Widder, E. A. \& Case, J. F. 1981. Two flash forms in the bioluminescent dinoflagellate, Pyrocystis fusiformis. J. Comp. Physiol. 143:43-52.

Wilson, T. \& Hastings, J. W. 2013. Bioluminescence: living lights, lights for living. Harvard University Press, Cambridge, MA, 185 pp.

Wohlrab, S., Iversen, M. H. \& John, U. 2010. A molecular and co-evolutionary context for grazer induced toxin production in Alexandrium tamarense. PLoS ONE 5:e15039.

Yoo, Y. D., Jeong, H. J., Kim, M. S., Kang, N. S., Song, J. Y., Shin, W., Kim, K. Y. \& Lee, K. 2009. Feeding by phototrophic red-tide dinoflagellates on the ubiquitous marine diatom Skeletonema costatum. J. Eukaryot. Microbiol. 56:413-420. 